\title{
Pengaruh Industri, Pangsa Pasar dan Web Traffic terhadap Kinerja Perbankan di Indonesia
}

\author{
Muhtad Fadly ${ }^{1)}$, Dias Setianingsih ${ }^{2 *}$ \\ ${ }^{1)}$ Program Studi Akuntansi, Fakultas Ekonomi dan Bisnis, Universitas Teknokrat Indonesia \\ Jl. ZA. Pagar Alam No.9 -11, Labuhan Ratu, Kec. Kedaton, \\ Kota Bandar Lampung, Lampung 35132 \\ ${ }^{2 *}$ Program Studi Manajemen, Fakultas Ekonomi, Universitas Samudra \\ Jl. Prof. Dr. Syarief Thayeb, Meurandeh Tengah, Langsa 24415 \\ E-mail: diassetianingsih@gmail.com
}

\begin{abstract}
ABSTRAK
Tujuan penelitian ini adalah untuk menguji secara empiris mengenai hubungan struktur industri, pangsa pasar, dan web traffic terhadap kinerja keuangan perusahaan pada industri perbankan di Indonesia. Penelitian ini menggunakan metode analisis data SEM-PLS menggunakan smartPLS. Data yang digunakan dalam penelitian ini adalah data sekunder dengan teknik pengambilam sampel menggunakan convenient sampling method, yang berjumlah 113 bersumber pada laporan keuangan bank yang ada di Indonesia dari laporan tahunan perusahaan yang diakses melalui situs resmi perbankan tersebut dan atau laporan keuangan bank yang ada di OJK tahun 2019. Hasil penelitian menunjukkan konsistensi baik menggunakan SEM-PLS maupun uji regresi linier berganda dapat disimpulkan bahwa masing-masing variabel yaitu: total asset, BUKU bank tipe bank, dan web traffic yang memiliki pengaruh secara signifikan terhadap pangsa pasar, dimana hanya variabel total asset yang memiliki arah pengaruh positif terhadap pangsa pasar, sedangkan variabel yang lain yaitu tipe bank, BUKU bank dan web traffic berpengaruh negatif terhadap pangsa pasar. Hasil penelitian juga menunjukkan bahwa kinerja keuangan perbankan yang diukur menggunakan ROE dipengaruhi secara signifikan oleh pangsa pasar dengan arah positif.
\end{abstract}

Kata Kunci: Kinerja Keuangan; Pangsa Pasar; ROE; Struktur Industri; Web Traffic

\begin{abstract}
The purpose of this study is to empirically examine the relationship between industry structure, market share, and web traffic on corporate financial performance in the banking industry in Indonesia. This research uses SEM-PLS data analysis method using smartPLS. The data used in this study are secondary data with a sampling technique using the convenient sampling method, amounting to 113 from the financial statements of banks in Indonesia from the company's annual reports accessed through the official banking website and / or bank financial reports in OJK. 2019. The results show consistency using both SEM-PLS and multiple linear regression tests, it can be concluded that each variable, namely: total assets, bank type bank booklet, and web traffic have a significant effect on market share, where only the total variable assets that have a positive influence on market share, while the other variables, namely bank type, bank $B U K U$ and web traffic, have a negative effect on market share. The results also indicate that the financial performance of banks as measured by ROE is significantly influenced by market share in a positive direction.
\end{abstract}

Keywords: Financial Performance; Industrial Structure; Market Share; ROE; Web Traffic 


\section{PENDAHULUAN}

Peningkatan kompetisi perbankan di Indonesia mulai dirasakan sejak adanya keterbukaan perbankan Indonesia dengan terbitnya paket kebijakan pada tanggal 1 Juni 1983 (PAKJUN) yang memodernisasi perbankan dan dilanjutkan dengan paket Oktober (PAKTO) pada tanggal 27 Oktober 1988 yang didalam nya memberi kemudahan perijinan pendirian bank baru, termasuk pembukaan kantor cabang. Saat itu, dengan dana Rp 10 miliar saja sudah dapat mendirikan sebuah bank baru. Hal ini menimbulkan persaingan diantara industri perbankan dalam menghimpun serta menyalurkan dana. Peningkatan jumlah bank berpotensi mendorong bisnis sektor perbankan menjadi lebih kompetitif dan meningkatkan efisiensi dan kesehatan perbankan. Hal ini telah menciptakan tantangan bagi semua jenis industri untuk berkompetisi, termasuk industri dibidang layanan perbankan, seiring dengan meningkatnya kegiatan produksi dan konsumsi masyarakat maka kebutuhan akan layanan perbankan semakin meningkat. Tumbuhnya persaingan diantara industri perbankan meningkat dengan pesat, baik untuk memenuhi kebutuhan pelanggan maupun agar mampu mengimbangi persaingan bisnis dan mengikuti perkembangan tuntutan masyarakat akan kebutuhan jasa perbankan.

Stuktur industri sangat mempengaruhi dalam menghasilkan kinerja yang optimal, baik dalam menghasilkan laba maupun pangsa pasar. Keberhasilan ataupun kegagalan industri untuk tetap dapat bisa melakukan aktivitas bisnisnya sangat dipengaruhi kondisi industri perbankan berkaitan erat secara langsung dengan kinerja, pangsa pasar, resiko simpanan maupun resiko kredit yang dihadapi oleh perbankan tersebut. Pengaruh industri, pangsa pasar dan kinerja keuangan perbankan merupakan salah satu indikator dalam menentukan apakah strategi industri yang digunakan oleh perusahan dalam industri perbankan sudah sesuai dengan harapan atas pertumbuhan industri. Saat ini persaingan dalam industri perbankan menuntut perusahaan memiliki daya saing yang unggul dan dukungan manajemen mampu untuk membuat perencanaan yang baik sehingga menghasilkan kebijakan terkait penggunaan sumberdaya perusahaan yang tepat sehingga menghasilkan peningkatan efisiensi dan efektifitas organisasi.

Hal ini berpengaruh pada kinerja perbankan di Indonesia terutama kinerja laba. Kondisi persaingan dalam industri perbankan sangat terkait dengan kinerja industri perbankan itu sendiri. Aspek pengaruh persaingan dan keberhasilan persaingan yang tepat dapat dilihat dari pangsa pasar dan kinerja keuangan, dimana pangsa pasar tentu berdampak langsung pada kinerja laba perusahaan. Profit yang dihasilkan oleh industri perbankan merupakan salah satu indikator yang digunakan untuk menentukan kinerja bank. Di dalam ruang lingkup industri 
perbankan sendiri, persaingan antar bank juga tidak kalah sengit. Bank bermodal kecil harus bersaing terbuka dengan bank besar di segmen yang sama. Pemicunya satu, yakni hampir semua bank menerapkan strategi sama terutama di segmen pasar ritel dan konsumsi (Kuncoro, 2016).

Laporan OJK mengenai statistik perbankan Indonesia 2019 menyatakan bahwa struktur industri pada industri perbankan di Indonesia masih dikuasai oleh bank-bank besar yaitu kelompok BUKU IV yang menguasai asset mencapai 45\%. Kelompok BUKU III menguasai total aset sebesar 37\%. Artinya, $82 \%$ struktur industri bank dikuasai bank dengan modal inti di atas Rp 5 triliun. Sisanya ialah pangsa pasar BUKU II dan I masing-masing 16\% dan 2\%. Hal tersebut di atas mencerminkan bagaimana tingginya dampak tingkat persaingan yang terjadi pada industri perbankan di Indonesia. Menurut laporan triwulan VI Bank Indonesia 2019, menyatakan bahwa simpanan pada industri perbankan tumbuh hanya $8 \%$ secara tahunan dan kredit perbankan tumbuh 9\%. Keduanya jauh lebih rendah bila dibandingkan dengan tiga tahun sebelumnya yang mampu tumbuh dua digit. Konsekuensinya, Loan to Deposit Ratio (LDR) naik menjadi 94\%. Dengan keterbatasan ruang gerak, perbankan pun masih terbelit kredit macet yang melebihi rasio 3\%. Imbasnya, kinerja fungsi intermediasi perbankan dihadapkan pada kendala klasik, yakni kinerja pertumbuhan laba.

Disisi kinerja dalam laporan OJK 2019 dinyatakan bahwa rasio profitabilitas dari aset atau Return on Assets (ROA) pada industri perbankan selama 2019 menurun akibat meningkatnya rasio kredit bermasalah atau Non-Performing Loan (NPL). Indikator ROA pada 2018 menurun menjadi 2,23\% dari 2017 yang sebesar 2,32\%, OJK juga mencatat kredit perbankan sepanjang 2016 tumbuh 7,8\%, pertumbuhan kredit 2018 lebih lamban dibanding 2017 yang di kisaran 10\%. Selain ROA, Return on Equity (ROE) juga mengalami penurunan dari 20,9\% menjadi 19,1\% di akhir kuartal III 2018. (sumber: Laporan Statistik Perbankan Indonesia 2019, diolah)

Bain (1951) menyatakan bahwa profit yang dihasilkan oleh industri perbankan merupakan salah satu indikator yang digunakan untuk menentukan kinerja bank. Berdasar pada hipotesis Stucture Conduct Performance (SCP) menyatakan bahwa struktur industri akan menentukan bagaimana industri berperilaku sehingga dari struktur dan perilaku tersebut akan menentukan kinerja industri. Fenomena atas hubungan antara industri, pangsa pasar dan kinerja perusahaan mengacu pada hipotesis SCP dalam hal ini ukuran perusahaan dan jenis perbankan serta pangsa pasar simpanan dan kredit akan berpengaruh kinerja perbankan.

Disisi lain persaingan pada industri perbankan di Indonesia juga secara berkesinambungan mengembangkan bisnis mereka baik melalui inovasi produk, layanan jasa 
perbankan sampai dengan perluasan cabang atau jaringan. Perbankan mengalami perubahan signifikan terkait teknologi informasi, teknologi baru seperti sistem operasi komputer canggih, jaringan area lokal dan internet, menjadi area strategis yang signifikan bagi perusahaan perbankan. Perbankan di Indonesia saat ini sudah mulai mengurangi pembukaan cabang. Kedepannya ada kemungkinan trend penutupan cabang bank. Ini dikarenakan perkembangan teknologi perbankan sudah memungkinkan untuk menurunkan jumlah nasabah yang harus berkunjung ke kantor cabang bank. Untuk mengimbangi perkembangan teknologi perbankan, beberapa strategi perbankan mengalami pergeseran. Digital Marketing mendapatkan fokus dan perubahan yang paling dramatis.

Berkaitan dengan hal tersebut pertumbuhan kegiatan berbasis web, khususnya disebabkan pertumbuhan bisnis e-commerce membuat kinerja web traffic data menjadi semakin berharga untuk dianalisis, hal ini dikarenakan keberhasilan sebuah strategi perbankan dalam hal terknologi informasi tidak hanya berfokus pada aspek jaringan teknologi saja, namun diperlukan pula sistem informasi yang baik. Analisis web traffic sangat diperlukan bagi perusahaan dalam menunjang kegiatan perbankan dimasa mendatang yang mengarah kepada persaingan teknologi dan juga sistem informasi. Ada berbagai sumber utama data web traffic, masing-masing dengan metode pengumpulan data yang berbeda dan traffic metric yang berbeda, namun disisi akuntansi akan tetap timbul pertanyaan mengenai keuntungan dan kerugian relatif dari pengukuran yang berbeda terkait pengaruh web traffic terhadap kinerja keuangan perusahaan.

\section{Struktur Industri}

Menurut Thompson et al. (2010), identifikasi stuktur industri adalah tahap awal dalam mengidentifikasi strategi perusahaan. Identifikasi struktur industri dapat memberikan gambaran tentang industri yang ada dan memberikan pandangan tentang kondisi persaingan secara luas. Oleh karena setiap industri akan memiliki karakteristik yang berbeda-beda, hal itu membuat semacam denah tentang lanskap industri yang dapat memberikan pandangan bagi perusahaan untuk mengerti arah strategi perusahaan bila dibandingkan dengan kondisi ekonomi di sekitar lingkungan industri tersebut.

Keunggulan bersaing merupakan jantung dari kinerja perusahaan di dalam persaingan (Porter, 1980). Setiap perusahaan tentu memiliki keuggulan bersaing yang berbeda dengan perusahaan sejenis yang dimana perbedaan itu dapat dijadikan kekuatan oleh perusahaan tersebut untuk bersaing. Persaingan dalam suatu industri biasanya didasari oleh struktur industri dimana perusahaan tersebut bersaing. Persaingan antara perusahaan dalam suatu industri guna mendapatkan posisi yang paling mengguntungkan 
baginya, persaingan ini dapat menggunakan berbagai macam cara seperti persaingan harga, pelayanan, iklan, dan lain lain. Persaingan ini terjadi karena perusahaan merasa posisinya teracam oleh pemain lain dalam industri tersebut.

Menurut Besanko (2010) intensitas persaingan ini dapat di tentukan oleh beberapa faktor, sebagai berikut seperti:

1. Jumlah dan ukuran perusahaan dalam suatu industri

2. Diversifikasi produk dalam suatu industri

3. Tingkat pertumbuhan industri

4. Halangan untuk keluar dari suatu industri

5. Dan lain-lain.

\section{Pangsa pasar}

Pangsa pasar adalah seberapa besar suatu perusahaan menguasi pasar yang di perhitungkan dengan persen. Pangsa pasar dalam praktik bisnis merupakan tujuan/motivasi perusahaan. Perusahaan dengan pangsa pasar yang lebih baik akan menikmati keuntungan dan penjualan produk dan kenaikan harga sahamnya (Wihana, 2008). Cravens (2000) berpendapat bahwa pangsa pasar berperan penting dalam perusahaan terkait hal seperti manajemen pelanggan, manajemen rantai nilai dan penciptan nilai pelanggan, strategi pemasaran memberikan konsep dan proses untuk mendapatkan keunggulan kompetitif dengan memberikan nilai lebih tinggi untuk pelanggan bisnis. Dengan meningkatnya persaingan di pasar domestik dan internasional, tuntutan atas kebutuhan dan keinginan pelanggan yang semakin menuntut dan tegas, kemajuan teknologi yang pesat, perubahan kebijakan dan undang-undang pemerintah, lingkungan pemasarannya berubah secara dramatis dalam dekade terakhir dan menjadi lebih bergolak (Cravens et al., 2000; Jain, 1997). Oleh karena itu, untuk menghadapi tantangan saat ini, bisnis harus memiliki strategi pasar yang lebih fokus dan terarah yang harus mereka terapkan secara efektif dan efisien (Cravens et al., 2000).

Khmarskyi et al., (2017) mengatakan bahwa bank modern saat ini menggunakan strategi dan pemilihan pasar yang berbeda-beda dalam aktivitas mereka, namun strategi ini dimungkinkan tidak efektif di pasar perbankan yang sangat kompetitif. Setiap bank mencoba untuk mencapai pangsa pasar yang diharapkan menghasilkan keuntungan yang tinggi. Di sisi lain, mengingat tingkat daya saing di pasar perbankan, ia harus mengeluarkan banyak uang untuk pemasaran instrumen. Isu pangsa pasar, strategi perusahaan, dan kineja keuangan tetap diminati bagi semua bank, perusahaan memutuskan strategi dimana mereka akan bersaing, bagaimana cara mengevaluasi 
aktivitas pemasaran, dan instrumen mana yang paling efektif.

Menurut teori kekuatan pasar, pangsa pasar adalah penentu kinerja potensial perusahan dan perilaku manajer dalam mencapai kinerja perusahan. Pangsa pasar sebagai proxy pilihan strategis bank menunjukkan bahwa adanya hubungan antara pangsa pasar dan kinerja bank yang tercerminkan pada efek efisiensi biaya. Secara keseluruhan, diversifikasi memungkinkan bank untuk meningkatkan pangsa pasar dan mengurangi risiko. Oleh karena itu penting untuk mempertimbangkan efek gabungan dari pangsa pasar dan pilihan strategis untuk mempelajari hubungan antara pangsa pasar dan kinerja (Mora et al., 2005).

Mullineaux (2010) mengklasifikasi pasar berada pada tingkat rata-rata tertimbang dari setiap pangsa pasar berdasarkan persentase bank total deposito tahunan di setiap negara bagian. Pasar perbankan merupakan pelanggan potensial yang menarik untuk bank untuk dilayani. Pangsa pasar suatu perusahaan dapat dicapai melalui distribusi, pelanggan akhir diberi produk-produk yang inovatif, atau produk-produk bermutu tinggi. Pangsa pasar digunakan untuk mengukur posisi perusahaan dalam persaingan industri. Semakin tinggi pangsa pasar mencerminkan semakin tinggi kekuatan perusahaan dalam persaingan pasar.

\section{Web traffic}

Literatur dari database LISTA (Library, Information Science \& Technology Abstracts) mengungkapkan studi tentang web traffic. Dalam tinjauan mereka tentang penelitian Webometrics, Thelwall et al, (2005) menjelaskan tentang analisis web traffic sebagai analisis lalu lintas yang difokuskan pada analisis log server web, yang mengandung arti lalu lintas data dari satu situs tertentu.

Salah satu web traffic yang umum digunakan adalah PageRank. Pada tingkat matematika, algoritma PageRank adalah logika matematika dalam menemukan Eigen vector utama dari matriks yang dibuat dari struktur pada tautan sistem. Lebih deskriptif, PageRank mengkodekan matriks model pengunjung website mengunjungi halaman sebuah website secara berturut-turut. Sistem peringkat yang dihasilkan menjadi target banyak tautan, karena pengunjung lebih mungkin melompat ke website. Ini juga memberi bobot lebih banyak tautan dari laman sumber yang lebih penting karena sumber-sumber ini lebih mungkin untuk melompat ke dan, oleh karena itu, lebih mungkin memulai lompatan baru (Brin dan Page, 1998).

\section{Kinerja keuangan}

Laporan keuangan perbankan merupakan suatu data historis yang merekam 
kejadian-kejadian yang terjadi di perusahaan yang memiliki nilai ekonomis. Laporan keuangan merupakan salah satu cara yang dapat digunakan oleh perusahaan untuk melihat kinerjanya dimasa lalu. Pada mulanya laporan keuangan bagi suatu perusahaan hanyalah sebagai rekaman data historis yang memiliki nilai ekonomis, tetapi untuk selanjutnya laporan keuangan dapat digunakan untuk menentukan atau menilai posisi keuangan perusahaan tersebut, Menurut IRFS (2007) laporan keuangan adalah suatu penyajian standar tentang aktifitas keuangan dari suatu perusahaan, individu, atau organisasi. Pemanfaatan laporan keuangan yang lebih lanjut ialah dengan menggunakan analisis rasio. Analisis rasio digunakan untuk mengetahui dan membandingkan akun dalam satu laporan keuangan dan kinerjanya terhadap akun dalam laporan keuangan pada priode yang sama.

\section{Perumusan Hipotesis}

Pengaruh Struktur Industri Perbankan terhadap Pangsa Pasar Perbankan di Indonesia

Struktur industri sangatlah berpengaruh pada kinerja keuangan industri tersebut, struktur industri yang berkinerja baik akan dapat bertahan di tengah persaingan industri dan akan meningkatkan kinerja industri secara keseluruhan. Menurut Besanko (2010) intensitas persaingan ini dapat di tentukan oleh beberapa faktor, termasuk didalam nya adalah ukuran perusahaan dalam suatu industri dan diversifikasi produk dalam suatu industri. Salah satu aspek dalam struktur industri adalah ukuran perusahaan. Ukuran perusahaan yang diukur dengan asset perusahaan menunjukkan seberapa besar harta yang dimiliki perusahaan. Perusahaan dengan asset yang besar maka akan menggunakan sumber daya yang ada semaksimal mungkin untuk menjangkau pangsa pasar yang lebih maksimal dan perusahaan. Sehingga hipotesis yang pertama adalah sebagai berikut:

H1a: Total asset perbankan berpengaruh positif dan signifikan terhadap pangsa pasar perbankan di Indonesia.

H1b: Buku bank berpengaruh positif dan signifikan terhadap pangsa pasar perbankan di Indonesia.

H1c: Tipe bank perbankan berpengaruh positif dan signifikan terhadap pangsa pasar perbankan di Indonesia.

\section{Pengaruh Web Traffic Perbankan terhadap Pangsa Pasar Perbankan di Indonesia}

Banyak penelitian telah membahas dampak potensial dari internet pada banyak industri yang berbeda, dan pada perbankan ritel pada khususnya. Namun, dominan studi sebelumnya sebagian besar bersifat penyelidikan pada perusahaan yang berhasil 
menerapkan strategi teknologi mereka, dan dengan demikian, studi ini tidak memiliki dukungan empiris yang ketat (Sriram dan Krishnan, 2003). Dengan demikian, kita masih tahu sedikit tentang dampak sebenarnya dari internet banking terhadap kinerja bank (DeYoung et al., 2007). Memang, Hernando \& Nieto (2007) mengeluh bahwa ada kelangkaan nyata studi empiris memberikan analisis kuantitatif dampak internet terhadap kinerja bank. Jelas lebih banyak penelitian tentang internet banking dibenarkan. Selanjutnya, studi-studi yang telah dilakukan tidak memadai. Beberapa studi empiris yang membahas dampak internet banking biasanya hanya membandingkan karakteristik bank yang menawarkan e-commerce dengan yang tidak (Egland et al., 1998; Furst et al., 2000, 2002; Sullivan, 2000; Ciciretti et al., 2009; Carlson et al., 2001). Sehingga hipotesis yang diajukan adalah sebagai berikut:

$\mathrm{H} 2$ : Web traffic situs perbankan berpengaruh negatif dan signifikan terhadap pangsa pasar perbankan di Indonesia.

\section{Pengaruh Pangsa Pasar Perbankan terhadap Kinerja Keuangan Perbankan di Indonesia}

Penelitian Belkhaoui et al, (2014) menunjukkan bahwa struktur pasar memiliki pengaruh positif dan tidak langsung terhadap bank kinerja, dan pangsa pasar tersebut memiliki pengaruh positif dan langsung terhadap kinerja bank. Keberhasilan strategi pemasaran perusahaan yang tepat tentu dapat dilihat dari pangsa pasar yang dimili oleh perusahaan. Terdapat hubungan yang tidak pasti antara pangsa pasar dan kinerja keuangan perusahaan itu sendiri, secara teoritis strategi pemilihan pangsa pasar yang tepat akan berdampak langsung pada kinerja laba perusahaan. Mengutip Clark (2000) ia meneliti terkait keputusan manajerial saat ini menunjukkan bahwa fokus utama nya adalah pada mengalahkan pesaing, hal ini tersirat dari pengukuran pangsa pasar. Selanjutnya, ukuran pangsa pasar dianggap oleh perusahaan sebagai sebuah set kompetitif yang benar.

Hubungan antara kinerja pangsa pasar dan kinerja keuangan perbankan merupakan indikator penting dalam menentukan apakah strategi pemasaran yang digunakan oleh perusahan dalam industri perbankan sudah sesuai dengan harapan atas pertumbuhan perusahaan. Jika pangsa pasar semakin besar, diasumsikan dana pihak ketiga perbankan semakin tinggi, maka pendapatan perbankan akan meningkat. Hal ini disebabkan oleh keuntungan yang diperoleh dari pangsa pasar karena dengan pangsa pasar yang lebih besar akan mendorong efisiensi yang lebih baik (skala ekonomi). Semakin besar pangsa pasar yang dimiliki maka kesempatan untuk memperoleh laba juga semakin besar. 
Sehingga hipotesis yang diajukan adalah sebagai berikut:

H3: Pangsa pasar perbankan berpengaruh positif dan signifikan terhadap ROE.

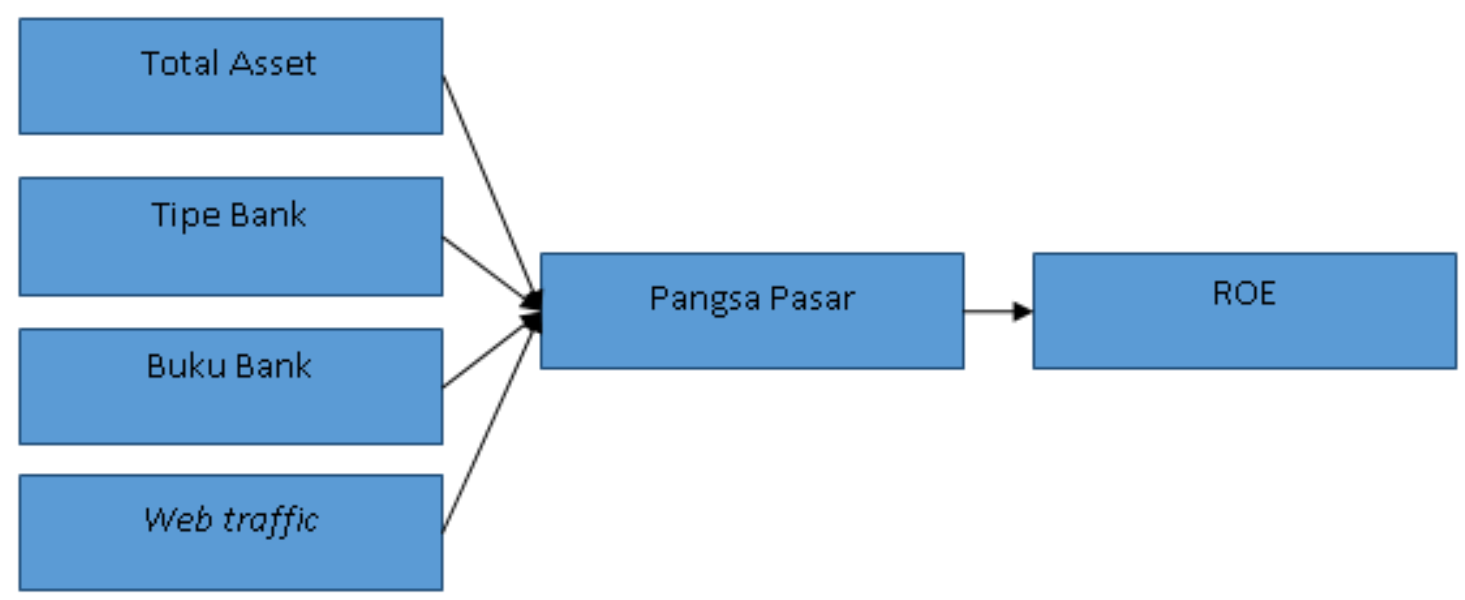

\section{Gambar 1. Model Penelitian}

\section{METODE PENELITIAN}

\section{Obyek penelitian}

Penelitian ini menggunakan pendekatan kuantitatif. Populasi penelitian ini adalah perusahaan perbankan yang terdaftar di OJK pada tahun 2019 dengan kriteria pemilihan sampel adalah perusahaan perbankan tersebut mempunyai laporan keuangan lengkap selama periode tahun sehingga dapat mendukung perhitungan variabel-variabel penelitian. Data yang digunakan dalam penelitian ini adalah data sekunder dengan teknik pengumpulan data bersumber pada laporan keuangan bank yang ada di Indonesia dari laporan tahunan perusahaan yang diakses melalui situs resmi perbankan. Penelitian ini menggunakan path analisis mengunakan Structural Equation Model (SEM) Partial Least Squares (PLS). Instrumen penelitian diuji dengan pengujian variabel intervening, pengujian Model Struktural (Inner Model) dan Koefisien Determinasi (R-Square).

\section{Pengujian penelitian}

\section{Pengujian Variable intervening}

Variable intervening umumnya diuji dengan strategi causal step berdasarkan ketentuan dari Baron dan Kenny (1986). Dalam pengujian dengan causal steps, peneliti harus mengestimasi tiga persamaan regresi berikut (Baron dan Kenny, 1986):

1. Persamaan regresi sederhana variabel intervening $(Y)$ terhadap variabel independen $(X)$.

2. Persamaan regresi sederhana variabel dependen $(Z)$ pada variabel independen $(X)$.

3. Persamaan regresi berganda variabel dependen $(\mathrm{Y})$ pada kedua variabel independen $(\mathrm{X})$ dan intervening $(\mathrm{M})$. 


\section{Pengujian inner model}

Pengujian inner model dilakukan untuk melihat hubungan antara konstruk atau variabel laten dilihat dari $R$-square, model penelitian dengan besar koefisien jalur strukturalnya. Stabilitas dari estimasi ini dievaluasi dengan mengunakan uji t statistik yang diperoleh lewat prosedur bootstrapping (Hulland, 1999).

\section{Pengujian hipotesis}

Secara umum metode confirmatory research adalah pendekatan metode yang menggunakan PLS. Hal ini disebabkan pada metode ini terdapat pengujian Hipotesis. Menguji hipotesis dapat dilihat dari nilai t-statistik dan nilai probalilitas. Untuk pengujian hipotesis menggunakan nilai statistik maka untuk alpha 5\% nilai t-statistik yang digunakan adalah 1,96. Sehingga kriteria pendukung atau tidak pendukung Hipotesis adalah Ha diterima dan H0 ditolak ketika t-statistik $>1,96$. Untuk mendukung atau tidak mendukung Hipotesis menggunakan probabilitas maka Ha di terima jika nilai $\mathrm{p}<0,05$.

\section{HASIL DAN PEMBAHASAN}

Berdasarkan temuan penelitian, variabel intervening pangsa pasar (PP) adalah variabel yang bersifat memperkuat atau memperlemah pengaruh variabel bebas (independen) terhadap variabel dependen.

Tabel 1. Hasil Pengujian Hipotesis Pertama

\begin{tabular}{clcc}
\hline $\begin{array}{c}\text { Causal } \\
\text { Step }\end{array}$ & \multicolumn{1}{c}{ Variable } & \multicolumn{2}{c}{ smartPLS } \\
\cline { 3 - 4 } & & $\begin{array}{c}\text { R } \\
\text { Square }\end{array}$ & R Square Adjusted \\
\hline a & Ln_TA, TB, BB, Ln_WT terhadap PP & 0.611 & 0.569 \\
b & PP terhadap ROE & 0.056 & 0.048 \\
c & Ln_TA, TB, BB, Ln_WT terhadap ROE & 0.069 & 0.035 \\
\hline
\end{tabular}

Sumber: data diolah 2019

Dari hasil tersebut diatas dapat disimpulkan bahwa variabel Pangsa pasar pada model pada penelitian ini adalah indirect-only mediation (intervening tidak langsung) hal ini dikarenakan variabel independen tidak signifikan mempengaruhi variabel dependen.

Selanjutnya hasil Uji $R$-Square baik menggunakan inner model (model struktural) yang dibentuk dari model menghasilkan nilai $R$-Square sebesar 0,611 untuk PP dan 0,056 untuk ROE. Hal ini menunjukkan bahwa penelitian ini memiliki hasil model yang moderate untuk model persamaan pertama dan lemah untuk model persamaan kedua. 
Tabel 2. Hasil Pengujian Hipotesis Kedua

\begin{tabular}{lcc}
\hline \multicolumn{1}{c}{ Variable } & \multicolumn{2}{c}{ smartPLS } \\
\cline { 2 - 3 } & R Square & R Square Adjusted \\
\hline TA, TB, BB, WT terhadap PP & 0.404 & 0.382 \\
PP terhadap ROE & 0.056 & 0.048 \\
\hline
\end{tabular}

Sumber: data diolah 2019

Tabel 1. Hasil Pengujian Hipotesis Ketiga

\begin{tabular}{lcc}
\hline \multicolumn{1}{c}{ Variable } & \multicolumn{2}{c}{ smartPLS } \\
\cline { 2 - 3 } & Original Sample (O) & Keterangan \\
\hline Ln_TA terhadap PP & 1.119 & Positif \\
TB terhadap PP & 0.002 & Positif \\
BB terhadap PP & -0.762 & Negatif \\
Ln_WT terhadap PP & -0.182 & Negatif \\
PP terhadap ROE & 0.237 & Positif \\
\hline
\end{tabular}

Sumber: data diolah 2019

Hasil pengujian hipotesis menggunakan smartPLS dimana hasil dari koefisien jalur dan nilai t-statistik yang didapat melalui proses bootstrapping, dengan syarat t-statistik harus lebih besar dari nilai kritis t sebesar 1,96 pada taraf signifikasni 5\%. Dari hasil path coefficient diatas dapat dilihat bahwa hanya proxy tipe bank (TB) pada variabel pangsa pasar (PP) dengan nilai T-statistik 0,311 < 1,96 tidak signifikan, hal ini menunjukkan bahwa tipe bank tidak berpengaruh terhadap pangsa pasar. Total asset perbankan berpengaruh positif dan signifikan terhadap pangsa pasar perbankan di Indonesia yang artinya total asset perbankan berpengaruh positif dan signifikan terhadap pangsa pasar perbankan di Indonesia. Buku bank berpengaruh positif dan signifikan terhadap pangsa pasar perbankan di Indonesia yang artinya tipe perusahaan perbankan tidak berpengaruh positif dan signifikan, namun berpengaruh negatif dan signifikan terhadap pangsa pasar perbankan di Indonesia. Tipe bank perbankan berpengaruh positif dan signifikan terhadap pangsa pasar perbankan di Indonesia yang artinya tipe bank berpengaruh negatif dan tidak signifikan terhadap pangsa pasar perbankan di Indonesia.

Beberapa hasil penelitian ini sejalan dengan penelitian yang dilakukan oleh Belkhaoui, et al. (2014) yang menemukan hubungan positif antara Structure Conduct Performance (SPC) dimana struktur industri dan struktur pangsa pasar perbankan di sebagian besar negara di studi menunjukkan bahwa struktur industri (konsentrasi persaingan) memiliki pengaruh positif terhadap pangsa pasar. Oleh karena itu, hasilnya memberikan bukti mendukung mengenai temuan hubungan antara struktur industri dalam perbankan dan pangsa pasar perbankan. Yang menjadi perbedaan adalah, bahwa pada penelitian ini struktur industri di proyeksikan pada Ukuran perusahaan (Total asset) dan buku bank dan tipe bank mengacu 
pada Peraturan Bank Indonesia Nomor 14/26/PBI/2012 tentang kegiatan usaha dan jaringan kantor berdasarkan modal inti bank yang membagi kelompok bank berdasarkan modal inti yang dimiliki oleh bank.

Yang menarik dalam pada penelitian ini adalah temuan bahwa tipe bank (konvensional atau syariah) tidak memiliki pengaruh signifikan terhadap pangsa pasar, hal ini dapat diartikan bahwa perkembangan pangsa pasar syariah di Indonesia belum maksimal. Meskipun beberapa upaya yang telah dilakukan oleh pemerintah OJK untuk mendorong inovasi pengembangan produk perbankan syariah, adalah penyederhanaan proses perizinan produk bank syariah dengan diterbitkannya POJK No.24/POJK.03/2015 tentang Produk dan Aktivitas Bank Syariah dan Unit Usaha Syariah. OJK juga mendorong industri perbankan syariah untuk menerbitkan produk bersama, telah dilakukan upaya untuk menerbitkan produk bersama perbankan syariah. Dengan dukungan tersebut belum berpengaruh pada pangsa pasar perbankan syariah di Indonesia.

Web traffic situs perbankan berpengaruh negatif dan signifikan terhadap pangsa pasar perbankan di Indonesia yang artinya web traffic situs perbankan berpengaruh negatif dan signifikan terhadap pangsa pasar perbankan di Indonesia. Hasil penelitian ini tidak sejalan dengan penelitian Callaway (2008) dan Vaughan \& Yang (2013) yang menemukan hubungan positif antara web traffic dan kinerja kualitas akademik, meskipun kinerja dalam penelitian tersebut bukan lah kinerja dalam industri perbankan. Sriram dan Krishnan, (2003) yang menyatakan bahwa dampak potensial dari internet pada banyak industri perbankan ritel pada khususnya namun dominan studi sebelumnya sebagian besar bersifat penyelidikan penerapan strategi teknologi pada perusahaan yang berhasil menerapkan strategi teknologi, studi ini tidak memiliki dukungan empiris yang ketat. Penguatan atas temuan pada penelitian ini adalah penelitian DeYoung, et al, 2007 yang menyatakan kita masih tahu sedikit tentang dampak sebenarnya dari internet banking terhadap kinerja bank.

Pangsa pasar perbankan berpengaruh positif dan signifikan terhadap ROE yang artinya pangsa pasar perbankan berpengaruh positif dan signifikan terhadap ROE. Hasil penelitian ini sejalan dengan penelitian yang dilakukan Belkhaoui, et al. (2014), Clark (2000) dimana hasil penelitian menunjukkan bahwa pangsa pasar tersebut memiliki pengaruh positif dan langsung terhadap kinerja bank. Mengutip Clark (2000) ia meneliti terkait keputusan strategi manajerial saat ini yang menunjukkan bahwa fokus utamanya perusahaan saat ini adalah pada mengalahkan pesaing, termasuk didalamnya aspek pengukuran pangsa pasar. Selanjutnya, ukuran pangsa pasar dianggap oleh perusahaan sebagai sebuah set kompetitif yang benar, hal ini menunjukkan bahwa peningkatan pangsa pasar merupakan hasil 
diferensiasi produk yang dilakukan oleh perusahan dan hal ini berhubungan profit yang dihasilkan dan merupakah hasil dari efisiensi perbankan. Hubungan antara kinerja pangsa pasar dan kinerja keuangan perbankan merupakan indikator penting dalam menentukan apakah strategi pemasaran yang digunakan oleh perusahan dalam industri perbankan sudah sesuai dengan harapan atas pertumbuhan perusahaan.

\section{KESIMPULAN}

Penelitian ini bertujuan memberikan bukti empiris mengenai pengaruh struktur industri dan web traffic terhadap pangsa pasar dan pangsa pasar terhadap kinerja keuangan perbankan di Indonesia. Dengan hasil yang konsisten baik menggunakan smartPLS variable struktur industri dan web traffic dalam mempengaruhi pangsa pasar adalah sebesar $61.1 \%$ dan sisanya $38.9 \%$ dijelaskan oleh variabel lain yang tidak termasuk dalam model penelitian ini, lalu variabel pangsa pasar terhadap ROE pada penelitian ini adalah sebesar 5.6\% dan sisanya yaitu sebesar $94.4 \%$ dijelaskan oleh variabel lain yang tidak termasuk dalam model penelitian ini.

Berdasarkan penelitian yang telah dilakukan, dengan meneliti sebanyak 113 bank terdapat di indonesia untuk periode penelitian tahun 2017, baik menggunakan smartPLS disimpulkan bahwa masing-masing variabel yaitu: total asset, buku bank, dan web traffic yang memiliki pengaruh secara signifikan terhadap pangsa pasar, sedangkan tipe bank tidak memiliki pengaruh signifikan terhadap pangsa pasar. Variabel total asset dan tipe bank memiliki arah pengaruh positif terhadap pangsa pasar, sedangkan variabel yang lain yaitu tipe bank dan web traffic berpengaruh negatif terhadap pangsa pasar. Hasil penelitian juga menunjukkan pengaruh pangsa pasar terhadap kinerja perbankan ROE, bahwa kinerja keuangan perbankan yang diukur menggunakan ROE dipengaruhi secara signifikan oleh pangsa pasar dengan arah positif.

\section{REFERENSI}

Bain, J. (1951). Relation of Profit Rate to Industry Concentration: American Manufacturing, 1936-1940. The Quarterly Journal of Economics, 65(3), 293-324. Retrieved September 7, 2020, from http://www.jstor.org/stable/1882217

Baron, R.M. \& Kenny, D.A. (1986), "The Moderator-Mediator Variable istinction in Social Psychological Research: Conceptual, Strategic, and Statistical Considerations", Journal of Personality and Social Psychology,

Belkhaoui, Samir \& Lakhal, Lassaad \& Lakhal, Faten \& Hellara, Slaheddine. (2014). Market structure, strategic choices and bank performance: a path model. Managerial Finance. 40. 538-564. 10.1108/MF-07-2013-0183.

Besanko, d, dranove, d, shanley, m, and schaefer, S. (2010), Economics of strategy, 5th Edition, John Wiley and Son, Singapore 
Brin, S. and Page, L. (1998), "The anatomy of a large-scale hypertextual web search engine" Computer Networks and ISDN Systems, Vol. 30 Nos 1-7.

Callaway, S. and Hamilton, R. (2008), "Managing disruptive technology: internet banking ventures for traditional banks", International Journal of Innovation and Technology Management, Vol. 5 No. 1, pp. 55-79.

Carlson, J., Furst, K., Lang, W. and Nolle, D. (2001), "Internet banking: market developments and regulatory issues", paper presented to Society of Government Economists Conference 2000, Washington, DC, November 17, available at: www.occ.treas.gov/netbank/SGEC2000.pdf

Ciciretti, Rocco \& Hasan, Iftekhar \& Zazzara, Cristiano. (2009). Do Internet Activities Add Value? Evidence from the Traditional Banks. Journal of Financial Services Research. 35. 81-98. 10.1007/s10693-008-0039-2.

Clark, Bruce. (2001). A summary of thinking on measuring the value of marketing. Journal of Targeting, Measurement and Analysis for Marketing. 9. 357-369. 10.1057/palgrave.jt.5740026.

Cravens, D.W. (2000), Strategic Marketing, 6th ed., McGraw-Hill, Boston, MA.

Cravens, D.W., Merrilees, B. and Walker, R.H. (2000), Strategic Marketing Management for the Pacific Region, McGraw-Hill, Sydney

DeYoung, Robert \& Lang, William \& Nolle, Daniel. (2007). How the Internet affects output and performance at community banks. Journal of Banking \& Finance. 31. 1033-1060. 10.1016/j.jbankfin.2006.10.003.

Egland, K., Furst, K., Nolle, D. and Robertson, D. (1998), "Banking over the internet" Quarterly Journal, Vol. 17 No. 4, Office of the Comptroller of the Currency.

Furst, Karen and Lang, William W. and Nolle, Daniel E., Internet Banking: Developments and Prospects (September 1, 2000). Office of the Comptroller of the Currency Economic and Policy Analysis Working Paper No. 2000-9, Available at SSRN: http://dx.doi.org/10.2139/ssrn.1988503

Hernando, Ignacio \& Nieto, Maria. (2006). Is the Internet Delivery Channel Changing Banks Performance? The Case of Spanish Banks. SSRN Electronic Journal. 10.2139/ssrn.930563.

Hulland, J. (1999). "Use of Partial Least Square (PLS) in Strategic Management Research: A Review of Four Recent.” Strategic Management Journal, 20(2):195.

IRFS. (2014). Summaries of International Financial Reporting Standards. https://www.iasplus.com/en/standards/ias/ias1

Jain, S.C. (1997), Marketing Planning and Strategy, 5th ed., South-Western College Publishing,Cincinnati, $\mathrm{OH}$

Khmarskyi, V.Y. \& Pavlov, Roman. (2017). Relation between marketing expenses and bank's financial position: Ukrainian reality. Benchmarking: An International Journal. 24. 903933. 10.1108/BIJ-02-2016-0026

Mora, Rodolfo \& Benitez, Mario. (2009). Profitability, Concentration and Efficiency in the Mexican Bank System. El Trimestre económico. 76. 237-263

Mullineaux, D.J. and Pyles, M.K. (2010), "Bank marketing investments and bank performance", Journal of Financial Economic Policy, Vol. 2 No. 4, pp. 326-345. https://doi.org/10.1108/17576381011100856

Sriram, Ram \& Krishnan, Gopal. (2003). The Value Relevance of IT Investments on Firm Value in the Financial Services Sector. IRMJ. 16. 46-61. 10.4018/irmj.2003010104.

Sullivan, D. (2002), "Google tops in 'search hours' ratings", available at: http://searchenginewatch.com/sereport/02/05-ratings.html

Porter, M.E. (1980) "From Competitive Advantage to Corporate Strategy", Harvard Business Review, May/June 1987. 
Thelwall, M., Vaughan, L., \& Björneborn, L. (2005). Webometrics. In B. Cronin (Ed.), Annual Review of Information Science and Technology, volume 39, p. 81 - 135.

Thompson, A.A., Gamble, J.E., and A. J. Strickland (2010), Crafting and Executing Strategy: Concept and Cases, $17^{\text {th }}$ Edition, McGraw-Hill, Singapore.

Vaughan, Liwen \& Yang, Rongbin. (2013). Web Traffic and Organization Performance Measures: Relationships and Data Sources Examined. Journal of Informetrics. 7. 699711. 10.1016/j.joi.2013.04.005.

Wihana, J,K. (2008). Ekonomi Industri, Yogjakarta: BPFE Yogjakarta. 